\title{
74- Spaces of restorative healing in the poetry of Emily Dickinson, Elizabeth Bishop, and Mary Ruefle
}

\section{Carl Jeffrey BOON ${ }^{1}$}

APA: Boon, C. J. (2021). Spaces of restorative healing in the poetry of Emily Dickinson, Elizabeth Bishop, and Mary Ruefle. RumeliDE Dil ve Edebiyat Araştırmaları Dergisi, (25), 1174-1184. DOI: 10.29000/rumelide.1039115.

\begin{abstract}
Recent scholarship suggests that Emily Dickinson, Elizabeth Bishop, and Mary Ruefle-three giants in the world of poetry who flourished in different centuries-should be more seriously considered as feminist writers that they previously have been. The present work makes a specific case to that effect by examining one poem of each, and argues that the poems offer and inscribe spaces in which readers (especially women readers) might reflect on their own experiences as women and, in doing so, encounter possibilities for emotional healing in a world still dominated by sexist or patriarchal modes of thought. Such readers are able to recognize themselves and their own stories inside the work. Healing becomes possible when that self-recognition is transformed into a sense of self-worth. In this sense, these three poets might be re-evaluated in terms of their contributions to feminist thinking owing to how they created their poems (form), and not merely what the poems say (content). Taken together, form and content in Dickinson's "I dwell in Possibility," Bishop's "In the Waiting Room," and Ruefle's "Keeping It Simple" offer spaces for restorative healing. The analyses here are augmented by new looks at old poetic concepts, including self-discovery, memory, nature, and the sublime.
\end{abstract}

Keywords: Poetry, Healing, Feminism

\section{Emily Dickinson, Elizabeth Bishop ve Mary Ruefle'ın şiirlerinde iyileştirici alanlar}

$\ddot{O} \mathbf{z}$

Son yıllarda yapılan çalışmalar, şiir dünyasında farklı yüzyıllarda ürünler veren Emily Dickinson, Elizabeth Bishop ve Mary Ruefle'ın, feminist yazarlar olarak daha ciddi olarak düşünülmesi ve değerlendirilmesi gerektiğini öne sürmektedir. Bu sebeple bu çalışma, yazarların ürünü olan şiirleri feminist perspektifle inceleyecektir. Ayrıca, bu çalışma ilgili şiirlerin, özellikle kadın okuyucular tarafından okunduğunda, erkek egemen ve cinsiyetçi düşünce dünyasında, kadın olarak kendi deneyimlerini yansitabilecekleri ve bunu yaparken de duygusal olarak iyileşebilme imkanı bulabilecekleri bir okuma yaklaşımı ortaya koyacaktır. Bu okuyucular, bu şiirlerin içerisinde kendi hikayelerini bulabilecek ve kendi deneyimlerinin yansımalarını keşfedeceklerdir. Bu okuma, yaşanan deneyimde, okuyucunun kendini tanıması ve bir anlamda kendi öz-değerini de farketmesi olacaktır. $\mathrm{Bu}$ çalışma, feminist perspektifle analiz edilen şiirlerin içerik ve form üzerinden okunması deneyimini ortaya koymasının yanı sıra, eski şiirsel kavramlar olan kendini keşif, bellek, doğa ve yüce kavramlarına da yeni bir lensle yaklaşı inceleyecektir.

Dr. Öğr. Gör., Dokuz Eylül Üniversitesi, Edebiyat Fakültesi, Amerikan Kültürü ve Edebiyatı Bölümü (İzmir, Türkiye), tuib1974@yahoo.com, ORCID ID: 00oo-0002-4355-8990 [Araştırma makalesi, Makale kayıt tarihi: 19.10.2021-kabul tarihi: 20.12.2021; DOI: 10.29000/rumelide.1039115] 
Anahtar kelimeler: Şiir, Şifa, Feminizm

Emotional healing-be it collective or personal-is incumbent upon restoration: the restoration of one's voice, way of thinking, body, or place in the world. It requires that one be heard, appreciated, or provided a stage or a space for reflection, even a temporary one. The premise to be explored here is that certain works of art can provide that space, and can extend those conditions to the spectator or reader. This paper explores such conditions of healing through the lens of poetry, specifically the relationships between writer and reader, and teacher and student. The inspiration for this project is a poem by Denise Levertov, a twentieth-century American poet often associated with the Beat movement, titled "The Secret," one I teach every semester. Foregrounded in the (often strained) relationship between a poet and her readers, it captures a moment of delight, a moment of transcendence, when

Two girls discover

the secret of life

in a sudden line of

poetry.

It just so happens that the "sudden line" was written by the speaker of the poem-this poem called "The Secret"-a woman who's unaware that any such secret exists. She's surprised, and later notes that she loves the two girls "for finding what / I can't find." That the girls have discovered a secret (the secret) indicates to me that they've found their voices, their lives, and in fact themselves through the creation of another-in this case, the artistic work. Magic happens when we contemplate art and find ourselves within it. Restoration begins when the work of art produces in a reader or spectator that sense that "I exist," that "I have a voice"; these are indicators of self-recognition. Healing is possible when that selfrecognition is transformed into a sense of self-worth. Poetry makes this process possible, for it offers a private, quiet, contemplative space for self-reflection. The finest of poets, including the ones presented here, remain cognizant through the creative process that when readers are able to pause and wonder, they are able to imagine themselves as part of the work. This paper explores possibilities for healing in those spaces offered by certain poems. Here I will examine three such spaces in three poems aside from Levertov's-three poems written by women whose careers spanned three different centuries: Emily Dickinson's "I dwell in Possibility" (466), Elizabeth Bishop's “In the Waiting Room," and Mary Ruefle's "Keeping It Simple." The question to be asked of these poems is how they offer spaces for emotional and restorative healing. The focus here will be on form rather than content; in other words, how the poems are made.

The opportunities for healing and restoration that poetry offers-and also the restorative sense that many poets discover through the writing process itself-should not be understood in the pop psychology sense of "therapy" or "release." Although reading and writing poems (or working creatively in general) can be a therapeutic experience, poetry should be understood as a process through which one regain her sense of self or wholeness. Jane Hirshfield notes that "the etymological root of both healing and health is the idea of 'wholeness.' To heal, then, is to take what has been broken, separated, fragmented, injured, exiled and restore it to wholeness."2 Such a process, according to Hirshfield, must be based in empathy:

Another element of poetry's capacity to act as a force of healing is its grounding in connection and interconnection. There is solace in recognizing that whatever happens to a person, someone before

$2 \quad$ Hirshfield's "Poetry, Permeability, and Healing" first appeared in the Spring-Summer 2018 issue of American Poets. 
us has known it as well. Poetry's evidence tells us that we are not singled out by our suffering; we are brought into the shared life of all who have lived and died before and with us.

Being connected means reading and writing with the sense life itself is a shared experience, one that people can, in fact, relate if given the reflective space to do so. The poems presented here provide that space.

One of the grandparents of American poetry, Emily Dickinson's critical reception and placement in the canon have undergone ebbs and peaks over the last century. First of all, the actual publication of her work, especially in terms of how her poems should be presented and arranged, has been an ongoing point of critical debate among scholars. As Dickinson didn't live long enough to oversee her legacy (and, of course, because while she was alive she had very little interest in sharing her work with an audience wider than a few trusted companions), her work itself became contested. Male editors like Thomas Wentworth Higginson, cornered by the interests of the market and general reading trends, attempted to make her work palatable by normalizing it formally; they attempted to standardize it by, for instance, by getting rid of the capitalizations of certain words and omitting some of the dashes that readers nowadays associate with a "Dickinson poem." It wasn't until the first definitive collection was published-by Thomas H. Johnson in 1955 (The Complete Poems of Emily Dickinson)-that readers were able to recognize in her the revolutionary qualities of text and presentation that we take as a given today. Subsequently, a number of new editions of Dickinson's work have appeared that continue the movement toward restoring her work toward its original presentation and vision. These include Cristanne Miller's Emily Dickinson's Poems: As She Preserved Them (2016) and R.W. Franklin's Reading Edition (1998). Within the academy, new scholarship on Dickinson abounds: she has emerged as a feminist hero, extensive writer of letters, and prolific gardener. She's also become a pop culture icon owing to a couple of recent biopics.

In examining "I dwell in Possibility" (originally numbered 466 in the Johnson collection), I will demonstrate how Dickinson's innovative form (coupled with the poem's content) opens up possible spaces where emotional healing can happen. The word "possibility," of course, stands as a useful starting-point for analysis, but we shall begin with an analysis of form prior to examining points of content or choices of language. In this poem, form and content work together and complement each other. Here is the poem in its entirety (this version first appeared in Franklin's Reading Edition (1998):

I dwell in Possibility-

A fairer House than Prose-

More numerous of Windows-

Superior-for Doors-

Of Chambers as the Cedars-

Impregnable of eye-

And for an everlasting Roof

The Gambrels of the Sky-

Of Visitors-the fairest-

For Occupation-This-

The spreading wide my narrow Hands 
To gather Paradise-

What should strike readers right away is Dickinson's liberal use of dashes. I count thirteen of them here, nearly in every line, and the question we must always ask as readers and critics is: Why? What does she desire to accomplish by including so many dashes? A formal choice in Dickinson's work, the dash is meant to perform a pair of related functions, and describing those functions will allow us to learn about the poem's content. First, they open up the text; they provide its language breathing room. Let's imagine that Dickinson had chosen different types of punctuation-the period, or perhaps the semicolon. Such choices would indicate closure; the period is, of course, the stop, the locked door. On the other hand, the dash is a kind of window that offers something more, something beyond the confines of the typical sentence. A window offers possibility. One may stand at a window, gaze out, and imagine worlds (and lives and feelings and meanings) beyond the walls of a room or a house. The dash, in short, offers spaces for dreaming, personal reflection, and imagination. It should come as no wonder, then, that Dickinson's metaphorical strategy in the poem is to consider the processes and reading and writing (of prose and poetry) in terms of structures. In the prose structure, the building is closed up; there are few doors and windows. In the poetry structure, windows and doors abound. 3 The process of reading and writing poetry is open and limitless. In the process, one's imagination is given reign to wonder, to think beyond the more limited confines of prose. Or-as Suzanne Juhasz (1983) points out-"those same windows and doors can as well outline the spaciousness that only the imagination can create, reminding us once again of the power that is derived from the cultivation of consciousness." Here we are reminded of a certain tradition of women's writing that seeks to carve out spaces: Virginia Woolf's A Room of One's Own comes to mind, an essay in which she famously claims how important personal space and financial security are for women writers. Her sentences meander, seem wistful, and thus challenge formally patriarchal ideas of precision. Ann Heilmann (1995) points out that "Places of regeneration which are highly evocative of a female tradition now [are] reclaimed, these rooms provide the space and inspiration necessary for moral and philosophical enquiry and, finally, artistic activity." Private space is important not only for "artistic activity," but also for the reception thereof.

I am especially drawn to Juhasz's notion of "the cultivation of consciousness" because the emphasis in this work-its point of empathy, as it were-lies with the reader of the poem and not its writer. While there's little doubt that Dickinson has both tasks in mind in "I dwell in Possibility" (the writer's and the reader's), this paper, again, assumes the reader's perspective-her thinking, positioning, and imagination when confronted with a poem. Dickinson's dashes offer spaces (or little windows) from which the reader of the poem is able to think beyond the poem and of her place in the world. More specifically, the poet generously and democratically provides her a space to think (a "room of one's own," after Woolf), to cultivate her consciousness and to ponder certain questions: Who am I in the world and what's my role? Who am I in relation to men and their literary tradition? For restorative healing to occur, one must be provided a space in which to situate one's thoughts and desires and compare them to those of others'. The restorative healing process here becomes a process not only of imagining and pondering, but also a kind of "occupation," which emerges as the keyword in the final stanza of the poem.

Occupation means more than work or the ways in which one keeps herself busy; more pointedly, it means a thing that the reader must perform to (re)discover herself or her place in the world. Traditionally, men don't have to perform such work because their place is always-already given or

3 This is not to argue, of course, that certain prose writing cannot offer the same spatial possibilities as poetry. Nowadays-and since at least the modernist era-experimental, hybrid, or poetry-like prose have become popular. Such work calls traditional notions of genre into question. 
supposed in society. Their expectations are always-already inscribed into the social fabric: assume a career, pursue dreams, make a name etc. Traditionally, men are expected to fall into such roles naturally. Women, on the other hand, must seek and open up spaces for themselves in the world. Those spacesaside from those proscribed, such as motherhood or nurturing-must be fought for. In this poem, Dickinson gives women those spaces where they can fulfill their true selves or "cultivate their consciousness." Thus, Dickinson should be read as a writer who empowers. An occupation-or meaningful work performed outside the home-provides women dignity and a sense of social contribution apart from motherhood and taking care of a family and home. The idea of home itself-if we follow through on Dickinson's metaphor of prose and structure-is a confining one for many women. "I dwell in Possibility" allows a way out of the house and a way into the world.

Recent scholarship has posited Dickinson as a pioneering feminist thinker, and has brought to bear her life as a lesbian. See, for example, Julie Dobrow's After Emily4 and Martha Ackmann's These Fevered Days. 5 Critics haven't regarded Elizabeth Bishop similarly, even though she, too, was a closeted lesbian who wrote compellingly about the lives of women. Like Dickinson, she was a private individual who let her work speak on her behalf. Until new scholarship began appearing in the 1990s, little was known about Bishop's private life and relationships. Megan Marshall's Elizabeth Bishop: A Miracle for Breakfast6, however, filled in some of the blanks in terms of the poet as a young woman, the tragedies she faced and overcame, and her long-time relationships with Lota de Macedo Soares and Alice Methfessel. My focus here will be on Bishop's oft-anthologized poem titled "In the Waiting Room," and how its explorations of memory and maturity contain spaces where readers can find rooms for themselves beyond the one portrayed in the poem.

"In the Waiting Room" (1971) is a narrative poem comprised of traditional sentences broken into lines; notions of form, therefore, need not be examined the way they were in the Dickinson poem. The poem tells a story through the filter-figure of a young girl who's accompanied her aunt to a dentist appointment. The speaker of the poem is an older woman remembering that particular experience; as such, the poem involves the work of remembering, which always inscribes distance and time. The work of remembering, itself, mirrors the work of poetic composition owing to the fact that, in each type of work, certain images, details, and scenes may be altered, expanded, or completely left out. Memories are inexact, and involve a kind of privileging of certain images or experiences over others. Something similar can be said for the creative process, in which writers choose what to leave in and what to leave out. One might call creative writing "conscious remembering." Considering the work of Richard Hugo, Max Garland (2020) puts it this way:

The poet [Hugo] goes on, partly recalling and partly fabricating a remembrance of place and time. Of course, we don't only remember "what we love," but also what we lose, lack, long for, and even loath. But this combination of recovery and creativity, the shaping, re-shaping, recalling and revising that constitutes memory is, perhaps not coincidentally, very much the process of poetry.

I am particularly drawn here to Garland's mention of "recovery and creativity," a pair of notions that go directly to heart of this project. Restorative healing contains both. It is a process of recovery, i.e.

After Emily: Two Remarkable Women and the Legacy of America's Greatest Poet (Deckle Edge, 2018) charts the influence of Mabel Loomis Todd and Millicent Todd Bingham on the poet's legacy.

These Fevered Days: Ten Pivotal Moments in the Making of Emily Dickinson (W.W. Norton, 2020) describes notable intersections of the poet's youth and her growing into a writer.

Houghton, Mifflin, Harcourt (2017). 
(re)gaining one's lost sense of self, and also a process of creativity in which one can rewrite or re-invent oneself. Here is the first stanza of "In the Waiting Room":

In Worcester, Massachusetts, I went with Aunt Consuelo

to keep her dentist's appointment

and sat and waited for her

in the dentist's waiting room.

It was winter. It got dark

early. The waiting room

was full of grown-up people,

arctics and overcoats,

lamps and magazines.

My aunt was inside

what seemed like a long time

and while I waited I read

the National Geographic

(I could read) and carefully

studied the photographs:

the inside of a volcano,

black, and full of ashes;

then it was spilling over

in rivulets of fire.

Osa and Martin Johnson

dressed in riding breeches,

laced boots, and pith helmets.

A dead man slung on a pole

-"Long Pig," the "caption said.

Babies with pointed heads

wound round and round with string;

black, naked women with necks

wound round and round with wire

like the necks of light bulbs.

Their breasts were horrifying

I read it right straight through.

I was too shy to stop.

And then I looked at the cover:

the yellow margins, the date. 
Suddenly, from inside, came an oh! of pain

-Aunt Consuelo's voicenot very loud or long.

I wasn't at all surprised;

even then I knew she was

a foolish, timid woman.

I might have been embarrassed,

but wasn't. What took me

completely by surprise

was that it was me:

my voice, in my mouth.

Without thinking at all

I was my foolish aunt,

I-we-were falling, falling,

our eyes glued to the cover

of the National Geographic,

February, 1918.

The speaker sets the stage for readers using both general and specific imagery. At first, we find ourselves in a dentist's waiting room that might be any waiting room in any city in America. Eventually, however, the details of the room accrete until we find ourselves in a very specific, almost personal, place that for a moment will represent the very world the young girl inhabits, a place replete with "grown-up people" and their winter clothes. The girl will have to find herself in this place (and, more crucially, against it), on her journey toward acquiring a sense of self, a sense that she, too, is a unique individual and not merely an extension of her aunt or family. Helen M. Dennis (2000) argues that the poem embarks upon

a

\begin{abstract}
quest for a sense of self, or a reassurance that one is anyone, [and] involves an investigation of the "similarities," that is, what is common to humanity, what constitutes human identity and in particular, female identity? This poem also articulates a resistance to female and familial identity: she confuses herself with her aunt-whose voice screams?-but she does not want to be confused with her aunt. Nor does she want to be the women in National Geographic. [The poem] recalls a childhood moment of terror about individual and human identity and shapes it into a characteristic expression of the "sublime."
\end{abstract}

Dennis's allusion here to the sublime offers a useful starting-point for analysis. Perhaps of any aestheticliterary term, the "sublime" is the most misused and least understood. Most people tend to think of the sublime through images given by the British Romantic poets: Shelley's "Mont Blanc" or Wordsworth's breathtaking landscapes in "Tintern Abbey"-some combination of the beautiful and the terrible, the holy and the unholy, simultaneously inspiring and terrifying viewers. The sublime instills in spectators (or readers) both wonder and fear. That much is accurate, but Slavoj Zizek (1993) takes the definition a step further. In Tarrying with the Negative: Kant, Hegel, and the Critique of Ideology, he characterizes the sublime as 
an intersection containing elements which are neither beautiful nor purposeful. Sublime phenomena (more precisely, phenomena which around in the subject the sentiment of the Sublime) are in no way beautiful; they are chaotic, formless, the very opposite of a harmonious form, and they also serve no purpose, i.e., they are the very opposite of those features that bear witness to a hidden purposefulness in nature (they are monstrous in the sense of the inexpediently excessive, overblown character of an organ or an object) (p. 46).

In short, according to Zizek, the sublime is "too much"; it repulses in the way-as he posits later-that "radical Evil" disgusts and repulses. One need only look at the girl in the poem looking at the photos in the National Geographic to gain a sense of her repulsion. "Their breasts were horrifying," she states. She almost can't look any further, but something in the magazine compels her to keep going, keep gazing. "I read it right straight through. / I was too shy to stop." Those breasts, like the "overblown" organ to which Zizek alludes, constitute the key image in the poem. Both feminine and absolutely foreign, they emerge as the symbol that encompasses the girl's entire experience of the room and becomes one of the catalysts (even more powerful than the voice of her aunt) that compel her to re-envision and re-make the waiting room space as hers. The breasts also force her to rethink (or think for the first time) what it means to be a mother, aunt, or woman. They represent a powerful part of her future, and both tantalize and frighten her as she begins to face her own sexuality. The poem concludes:

I said to myself: three days

and you'll be seven years old.

I was saying it to stop

the sensation of falling off

the round, turning world.

into cold, blue-black space.

But I felt: you are an $I$, you are an Elizabeth, you are one of them.

Why should you be one, too?

I scarcely dared to look

to see what it was I was.

I gave a sidelong glance

-I couldn't look any higher-

at shadowy gray knees,

trousers and skirts and boots

and different pairs of hands

lying under the lamps.

I knew that nothing stranger

had ever happened, that nothing

stranger could ever happen.

Why should I be my aunt,

or me, or anyone?

What similarities- 
boots, hands, the family voice

I felt in my throat, or even

the National Geographic

and those awful hanging breasts-

held us all together

or made us all just one?

How-I didn't know any

word for it-how "unlikely"...

How had I come to be here,

like them, and overhear

a cry of pain that could have

got loud and worse but hadn't?

The waiting room was bright

and too hot. It was sliding

beneath a big black wave,

another, and another.

Then I was back in it.

The War was on. Outside,

in Worcester, Massachusetts,

were night and slush and cold,

and it was still the fifth

of February, 1918.

Through and against the triple terrors of seeing those breasts, her aunt's forlorn cry, and "the sensation of falling off / the round, turning world / into cold, blue-black space," the girl is finally able to imaginethrough a series of questions-herself as an individual with agency; she begins to identify as an actor and not one merely acted upon. When she asks the seemingly naïve question, "Why should I be my aunt, / or me, or anyone?” she's actually begun the process of individuation, of recognizing-in the most critical sense-herself as a powerful force in-dare I say?-the universe. It should strike us as no coincidence that the poem ends out there, on the street, in the world, with the reference to the Great War itself all the way over in Europe, for in time these will be the domains upon which the girl continues to move, think, and imagine. They will become her space, the space is which she will live as a woman in a world still bathed in patriarchal values.

Whereas a dentist's waiting room in Bishop's poem serves as the catalyst-space for the girl's selfdiscovery and re-creation, the contemporary poet Mary Ruefle turns to the outdoors in her brief and lyrical "Keeping It Simple":

I take the bird on the woodpile,

separate it from its function, feather

by feather. I blow up its scale.

I make a whole life out of it: 
everywhere I am, its sense of loitering

lights on my shoulder.

Although the poem consists of six lines unbroken by white space, it would behoove us to consider it in two parts (as in the way we usually consider a sonnet in the first eight lines and last six, with the concluding sestet "figuring out" or "answering" the situation posed by the octave). In Ruefle's poem, the first four lines pose a situation of "activity" wherein the speaker interacts with a bird, deconstructing it and making something new of it-"a whole life." In the final two lines, she turns inward to consider herself in relationship with the bird and how it might develop as the two figures move forward. It will be "everywhere I am," she concludes, noting that in essence the two will move forward as one living entity.

Ruefle's turning toward nature and contemplating its interactions with the human are emblematic of her work as a whole. And in "Keeping It Simple," the interaction between the speaker and the bird reaches toward metaphor. In Madness, Rack, \& Honey, a collection of lectures, Ruefle (2012) defines metaphor as "simply, an exchange of energy between two things" (p. 131). Here, the exchange of energy between the speaker and the bird will serve to enlarge the lives of both; "its sense of loitering / [that] lights on [her] shoulder" will transform the speaker into something more than she had been before and restore (and augment) her sense of self, her being an active and crucial participant in the affairs of the world. She will come away from the experience as a more complete human being. It's fitting that the bird presented here is not the traditional, soaring bird of poetry, but rather a still bird that almost seems imagined-that almost seems to be an extension of the speaker herself. It's appropriate because both figures in the poem must learn new functions: for the bird, how to be flightless; for the speaker, how to make a life, "a whole life" as a woman in the world.

Ruefle's poem, in addition to its compatibility with the work of Dickinson and Bishop, offers a useful point of conclusion owing to the fact that "Keeping It Simple" is an extended metaphor, and perhaps we have been dancing around the notion of metaphor all along. Ruefle defines metaphor as an "exchange of energy," but the key point is that an exchange of energy-be it real and kinetic or quietly spiritualshould be understood as an altering process that eventually produces something new. The figure in Ruefle's poem, the actor who makes a life out of the bird, through an exchange of energy, is able to make a new life for herself, as well. That new life would not have been possible without the speaker's discovery of the bird in the first place, just as in the Levertov poem in which the two girls discover a secret in the lines of a poem. For them, the trigger is the poem. For Bishop's young speaker, the trigger is the National Geographic magazine. Here, the trigger is the bird, which is central to the experience or event that begins the transformative process in which the speaker is able to become a different person. Metaphor in poetry denotes transformation.

The poems examined here-in different ways-offer places in which the central figures are freed to perform the emotional and intellectual work that leads to change, and that, in fact, allow them to become more complete human beings. Because the poets I've presented here are women (and particularly interested in what it means to be a woman), it's fitting to consider them in terms of gendered growth and development. These poets are generous in that they provide young woman spaces of their own that transform them and in which they can participate in their own transformation on their own terms. Their generosity is what makes these poems lasting tributes to women themselves, and sparks of resistance against old-fashioned ways of thinking about gender and expectations. 


\section{Bibliography}

Bishop, E. (1979). "In the Waiting Room.” The complete poems 1927-1979. Farrar, Straus \& Giroux. https://poets.org/poem/waiting-room.

Dennis, H.M. (2000). "Bishop and the Negative Sublime." In Kelly Lionel (ed.) Poetry and the sense of panic: critical essays on Elizabeth Bishop and John Ashbery. Rodopi. https://www.modernamericanpoetry.org/criticism/helen-m-dennis-waiting-room.

Dickinson, E. (1999). "I dwell in Possibility" (466). The poems of Emily Dickinson. Harvard University Press. https://www.poetryfoundation.org/poems/52197/i-dwell-in-possibility-466.

Garland, M. (2020). "The Poetry of Memory." Iowa Summer Writing Festival, June 2020.https://iowasummerwritingfestival.org/poetry-memory-0.

Heilmann, A. (1995). Feminist resistance, the artist and "A Room of One's Own." New Woman Fiction, Women's Writing, 2:3, 291-308.

Hirshfield, J. (2018). Poetry, permeability, and healing. American Poets. https://poets.org/text/poetrypermeability-and-healing.

Juhasz, S. (1983). The undiscovered continent: Emily Dickinson and the space of the mind. Indiana University Press. https://www.modernamericanpoetry.org/criticism/suzanne-juhasz-657-idwell-possibility.

Levertov, D. (1964). "The Secret." O taste and see: new poems. New Directions. https://www.poetryfoundation.org/poems/48725/the-secret-56d22a326e5a8.

Ruefle, M. (1982). "Keeping It Simple.” Memling's veil. University of Alabama Press. https://www.poetryfoundation.org/poems/53253/keeping-it-simple.

Ruefle, M. (2012). Madness, rack, \& honey. Wave Books.

Zizek, S. (1993). Tarrying with the negative: Kant, Hegel, and the critique of ideology. Duke University Press. 